\title{
Isolation and Characterization of a Myotoxic Fraction from Ceras- tes Vipera Snake Venom
}

\section{Introduction}

The bite of the viper Cerastes vipera has a serious medical problem. C. vipera venom contains a complex mixture of enzymes [1] including phospholipase $A_{2}[2]$ and proteases [3,4]. Some clinical effects following snake bite are due to $\mathrm{PLA}_{2}$ and proteases which are among the major components of viper venoms. Although these enzymes share a common cytotoxic activity and similar structural features with non-toxic mammalian pancreatic enzymes, they also promote a wide variety of pathological symptoms in animals, such as cardiotoxicity, myotoxicity, anticoagulant activity and hemolysis [5-7]. Since phospholipase $\mathrm{A}_{2}$ is almost invariably the most toxic component of the venoms, it probably plays an important role in mortality and morbidity following snakebite $[5,8]$. The primary target of PLA is the cell membrane inducing the hydrolysis of its phospholipids [9] as the hydrolysis of erythrocyte membrane [10-12] and the damage of the muscle cell membrane inducing myonecrosis [13-15]. A few PLA of the vipers have been isolated and purified $[2,9,16,17]$. The study of myotoxicity of Cerastes vipera venom has received relatively little attention $[18,19]$. The purposes of the present study are (a) to isolate a fraction having a myonecrotic effect with PLA 2 activity from Cerastes Vipera venom, (b) to evaluate the biological properties of the fraction, and (c) to investigate the antimyotoxic action of dexamethasone, Vit $\mathrm{E}$ and $\mathrm{C}$ and trypsin for the isolated fraction.

\section{Materials and Methods}

\section{Venom and chemicals}

Cerastes vipera venom was extracted from adult vipers collected from Aswan area and maintained in the Venom Research Lab, Department of Zoology, Faculty of Science, Ain Shams University. Venom was collected from the vipers every four weeks for a sixmonth period by allowing the vipers to bite through a rubber glove

\section{Journal of} Toxins

\author{
A. Abd El - Aal1, Eman A. Abd El-Ghffar ${ }^{1^{*}}$ and \\ Mohamed Mostafa Soliman ${ }^{1,2}$ \\ ${ }^{I}$ Department of Zoology, Faculty of Science, University of Ain Shams, \\ Egypt \\ ${ }^{2}$ Biology Department, Faculty of Science, Jazan university, KSA \\ *Address for Correspondence \\ Eman A. Abd El-Ghffar, Department of Zoology, Faculty of Science, Ain \\ Shams University, Cairo, Egypt, E-mail: eman_a@sci.asu.edu.eg \\ Submission: 3 March, 2017 \\ Accepted: 10 May, 2017 \\ Published: 15 May, 2017 \\ Copyright: @ $2017 \mathrm{El}$ - Aal AA, et al. This is an open access article dis- \\ tributed under the Creative Commons Attribution License, which permits \\ unrestricted use, distribution, and reproduction in any medium, provided \\ the original work is properly cited.
}

covering a glass funnel that emptied into a glass tube in the ice. The venom was lyophilized and stored at $4{ }^{\circ} \mathrm{C}$ until used. Sephadex G-75, phosphatidylcholine, casein (fat-free), sodiumdodecylsulfate (SDS), 2-mercaptoethanol, acrylamide, coomassie brilliant blue R250, trypsin, bovine serum albumin dexamethasone, Vit E, vitamin C and protein molecular weight markers were obtained from Sigma Chemical Co.

\section{Animals}

Male CD-1 White mice weighing approximately 20-25 g were housed in specially designed cages and maintained in conditions of good ventilation, normal temperatures, and humidity ranges. Mice were housed 5 animals in each cage to avoid crowding under conditions of equal periods of light and dark in the animal house (12 hr light and $12 \mathrm{hr}$ dark cycle). Mice were fed on standard pellets, containing all nutritive elements (proteins, fats, carbohydrates, vitamins, salts and minerals). Drinking water and food were provided ad libitum throughout the period of study. All experiments followed the ethical standards for animal experiments in toxicological research recommended by the International Society of Toxinology [20].

\section{Fractionation of Cerastes vipera venom}

Samples of lyophilized Cerastes vipera venom (110 mg) were reconstituted in $5 \mathrm{ml} 0.03 \mathrm{M}$ ammonium acetate buffer, $\mathrm{pH} 4.6$ and applied to a $2.5 \times 75 \mathrm{~cm}$ column (Pharmacia Biotech, Piscataway, NJ, USA) packed with Sephadex G-75 equilibrated with the same buffer and eluted at a flow rate of $1 \mathrm{ml} / \mathrm{min}$ using an EP-1 Econo Pump (BioRad Laboratory, Hercules, CA, USA). Five-milliliter fractions were collected, and elution profile was monitored at $280 \mathrm{~nm}$.

\section{Hemolytic activity of Cerastes vipera venom and its fraction}

Hemolytic activity of the crude venom and its isolated venom fraction was determined by measuring the release of hemoglobin from rabbit erythrocytes enhanced by the addition of phosphatidylcholine. This indirect hemolytic protocol was performed in glass tubes. $10,20,40$ and $60 \mu \mathrm{g}$ of the crude venom and its isolated fraction were added to a prewarm (to $37^{\circ} \mathrm{C}$ ) assay mixture containing 0.1 $\mathrm{ml}$ of phosphatidylcholine suspension $(10 \mathrm{mg} / \mathrm{L}), 1 \mathrm{ml}$ of rabbit erythrocytes $(2.5 \% \mathrm{v} / \mathrm{v})$ and $2.9 \mathrm{ml}$ of Tris buffer $(1 \mathrm{mM}, \mathrm{pH} 7.5)$ 
Citation: Abd El - Aal A, Abd El-Ghffar EA, Soliman MM. Isolation and Characterization of a Myotoxic Fraction from Cerastes Vipera Snake Venom J Toxins. 2017;4(1): 9

ISSN: $2328-1723$

containing $\mathrm{NaCl}(100 \mathrm{mM}), \mathrm{KCl}(100 \mathrm{mM})$ and $\mathrm{CaCl}_{2}(10 \mathrm{mM})$. After incubation for $1 \mathrm{hr}$, the tubes were centrifuged at $2500 \mathrm{~g}$ for 15 min using IEC-Centra-4R cooling centrifuge (I. E. Company, USA). The supernatant was used to estimate the degree of hemolysis at 540 $\mathrm{nm}$. Hemolytic unit (HU50) value is the amount venom or a fraction caused 50\% hemolysis and was calculated according to the method of [21].

\section{Myotoxic activity of the venom and fractions}

Ten fractions obtained from the viper venom were tested for their ability to induce myonecrosis by intramuscular (i.m.) injection into male white CD-1 mice $(n=3)$. After 3 hours, the mice were anesthetized with ether and killed by cervical dislocation. Samples of serum and muscle tissue were taken and processed as described by Rodrigues et al. [22]. Myotoxicity was assessed by the increase in serum Creatine Kinase (CK) activity, in addition to the determination of myonecrotic index using histological analysis.

\section{Essay of $\mathrm{PLA}_{2}$ of Cerastes vipera myotoxin}

The PLA $\mathrm{P}_{2}$ activity of the CV-PL-F4 myotoxin fraction was determined using the method described by Joubert and Taljaard [23]. $1 \mathrm{ml}$ of egg yolk suspension was mixed with $4.0 \mathrm{ml} \mathrm{0.1} \mathrm{M} \mathrm{Tris}$ buffer, $\mathrm{pH} 8$, and $0.1 \mathrm{ml}$ of the enzyme and incubated at $30^{\circ} \mathrm{C}$. The decrease of the turbidity of the suspension was recorded at $740 \mathrm{~nm}$. The absorbance change between $5 \mathrm{~min}$ and $15 \mathrm{~min}$ intervals was taken as the relative amount of enzyme activity. One unit was defined as the amount of enzyme which produced a decrease of 0.01 in absorbance in $10 \mathrm{~min}$

\section{Proteolytic activity assay of Cerastes vipera myotoxin}

Proteolytic activity of CV-PL- $\mathrm{F}_{4}$ was estimated with casein (fatfree, $\mathrm{BDH}$, England) using the method described by Mandelbaum et al. [24]. The reaction mixture contained $1 \mathrm{ml}$ of a $2 \%$ casein solution in $0.2 \mathrm{M}$ Tris-HCL buffer, $8 \mathrm{mM} \mathrm{CaCl}_{2}$, at pH 8.8 and $1 \mathrm{ml}$ of Cerastes vipera myotoxin solution. After $30 \mathrm{~min}$ incubation at $37^{\circ} \mathrm{C}, 3 \mathrm{ml}$ of $5 \%$ trichloroacetic acid was added to the mixture and the precipitate was removed by filtration. The amount of acid soluble products was measured in $1 \mathrm{ml}$ of the filtrate by the method of Lowry et al. [25]. The specific caseinolytic action was defined as absorbance $/ \mathrm{min} / \mathrm{mg}$ of protein at $750 \mathrm{~nm}$.

\section{Electrophoresis}

Homogeneity and molecular weight of the crude venom and CV-PL-F4 fraction were determined by slab SDS-PAGE using the apparatus of Bio/PhoresisTM (Bio Gene Limited, England). The protein samples were dissolved in a sample buffer containing 0.01 $\mathrm{M}$ Tris- $\mathrm{HCl}$ ( $\mathrm{pH}$ 8.6) and 10\% SDS with 5\% 2-mercaptoethanol. After heating at $100{ }^{\circ} \mathrm{C}$ for $5 \mathrm{~min}$, the samples were subjected to electrophoresis following the procedure described in the Bio Gene Technical Bulletin No. 110. Slab gels were stained using Coomassie brilliant blue R 250. M.W. calibration markers were subjected to SDSPAGE electrophoresis together with the viper venom and CV-PL-F ${ }_{4}$. The reference proteins used were: $\beta$-lactoglobulin $(18,400)$, carbonic anhydrase $(29,000)$, ovalbumin $(45,000)$, phosphorylase b $(97,000)$ and myosin H-chain $(200,000)$.

\section{Protein determination}

Protein concentrations of crude venom, column eluates, and isolated fractions were measured by the method of Lowry et al. with bovine serum albumin as a standard or by spectrophotometric absorption at $280 \mathrm{~nm}$ [25].

\section{$\mathrm{LD}_{50}$ determination}

The amount of a venom or its fractions that are sufficient to kill 50 percent of a population of animals usually within a certain time is called median lethal dose $\left(\mathrm{LD}_{50}\right) . \mathrm{LD}_{50}$ was determined by Intraperitoneal (i.p.) injection of different CV-PL-F4 doses into male CD-1 White mice. The survival time for each mouse was recorded up to $24 \mathrm{hr}$. $\mathrm{LD}_{50}$ was calculated according to the method described by Meier and Theakston [26].

\section{Experimental protocol}

a- Myotoxic effect of Cerastes vipera venom and CV-PL-F4: Cerastes vipera venom $\left(10 \mu \mathrm{g} / 25 \mathrm{~g}\right.$ mice) or myotoxin CV-PL-F ${ }_{4}(30$ $\mu \mathrm{g} / 25 \mathrm{~g}$ mice) was dissolved in $0.1 \mathrm{ml}$ of $0.85 \% \mathrm{NaCl}$. The dose of Cerastes vipera venom used in this study was equal to the sub $\mathrm{LD}_{50}$, where the $\mathrm{LD}_{50}$ of the venom was equal to $15.62 \mu \mathrm{g} / 25 \mathrm{~g}$ mouse. CD-1 mice (64 animals) were divided into eight groups, each of eight animals. Six animal groups were i.m. injected in the dorsolateral aspect of the gastrocnemius muscle with either venom or CV-PL- $\mathrm{F}_{4}$ to study the effect of the viper venom and CV-PL- $\mathrm{F}_{4}$ for three-time intervals. Mice injected with the crude venom or CV-PL- $\mathrm{F}_{4}$ was sacrificed after 1,3 and $24 \mathrm{hr}$. The other two animal groups were injected with $0.85 \%$ $\mathrm{NaCl}$ only and were used as a control.

b- Antimyotoxic effect of dexamethasone, vitamins $\mathrm{E}$, and $\mathrm{C}$ and trypsin: Ten animal groups ( 80 mice) were used each of eight animals. Two animal groups injected i.m. with the saline solution containing $10 \mu \mathrm{g}$ of Cerastes vipera venom or $30 \mu \mathrm{g} \mathrm{CV}-\mathrm{PL}-\mathrm{F}_{4}$ and were used as control groups. Dexamethasone $(50 \mu \mathrm{g})$, Vit E $(0.1$ $\mathrm{mg})$ and $\mathrm{C}(4 \mathrm{mg})$ were mixed with $10 \mu \mathrm{g}$ Cerastes vipera venom or $30 \mu \mathrm{g}$ CV-PL-F $\mathrm{F}_{4}$ and i.m. injected in the dorsolateral aspect of the gastrocnemius muscle of six groups of mice respectively. Crude venom $(10 \mu \mathrm{g})$ or CV-PL-F $4(30 \mu \mathrm{g})$ was incubated for $1 \mathrm{hr}$ at $37^{\circ} \mathrm{C}$ with $50 \mathrm{mg}$ trypsin to hydrolyze the proteins of the crude venom or CV-PL-F 4 . The mixtures were centrifuged for $15 \mathrm{~min}$ at $3000 \mathrm{rpm}$. The supernatants of the venom and myotoxin were i.m. injected in the last two animal groups respectively. The ten animal groups were sacrificed after $3 \mathrm{hr}$.

Measurements of serum CK activity, serum creatinine level, and myonecrotic index: Blood was collected from all animal groups of experiments (a) and (b) to separate serum. Serum CK activity and creatinine level were determined using the method described by Szasz et al. and Annino and Giese respectively [27,28]. Evaluation of myotoxicity of Cerastes vipera venom and CV-PL- $\mathrm{F}_{4}$ was carried out by measuring serum CK activity using a commercial colorimetric kit (Randox Laboratories Ltd. UK). The myonecrotic index was determined also from thick sections of muscle tissue stained with hematoxylin-eosin and examined with the light microscope according to the method described by Rodrigues et al. [22]. Damage and vacuolated muscle fibers were counted for each of three sections of tissue per mouse to give a final vacuolation index for each mouse. Usually, 2000 cells were counted per mouse. A necrosis Index was calculated as a number of necrotic cells/total number of cells. 
Citation: Abd El - Aal A, Abd El-Ghffar EA, Soliman MM. Isolation and Characterization of a Myotoxic Fraction from Cerastes Vipera Snake Venom J Toxins. 2017;4(1): 9

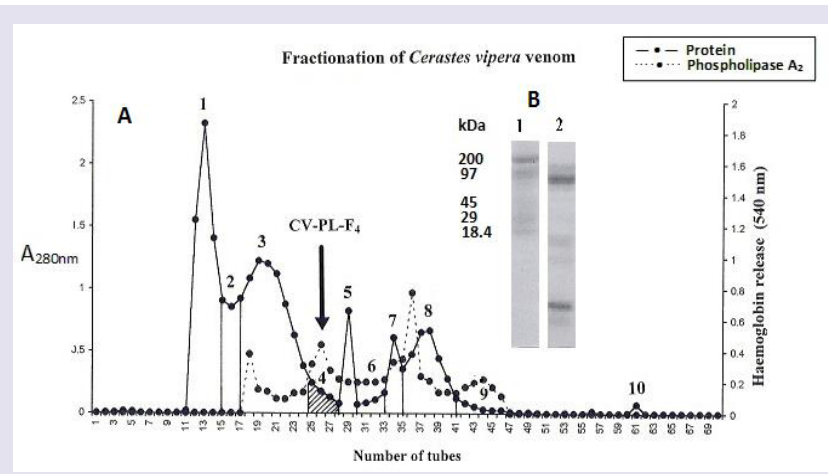

Figure 1: (A) Separation of Cerastes vipera venom by gel filtration on Sephadex G- 75 (2.5 x $75 \mathrm{~cm}$ column). Samples (110 mg) of crude venom, dissolved in $5 \mathrm{ml}$ of $0.03 \mathrm{~m}$ ammonium acetate buffer ( $\mathrm{pH} 4.6$ ), were applied to the column. The column was eluted with ammonium acetate buffer and tubes of $5 \mathrm{ml}$ were collected. The protein content of each tube was measured at $280 \mathrm{~nm}(--)$ and the degree of hemoglobin release was assayed at $540 \mathrm{~nm}(\cdots \cdots)$. Vertical lines indicate limits of the pools 1 to 10 . The fraction CV-PL-F4 (shaded peak) had myotoxic activity and was used in the present study. (B) SDS polyacrylamide gel electrophoresis of Cerastes vipera venom. Lane 1 contain $\beta$-lactoglobulin $(18,400)$, carbonic anhydrase $(29,000)$, ovalbumin $(45,000)$, phosphorylase b $(97,000)$ and myosin H-chain $(200,000)$ as molecular weight markers. Lane 2 contains Cerastes vipera venom.

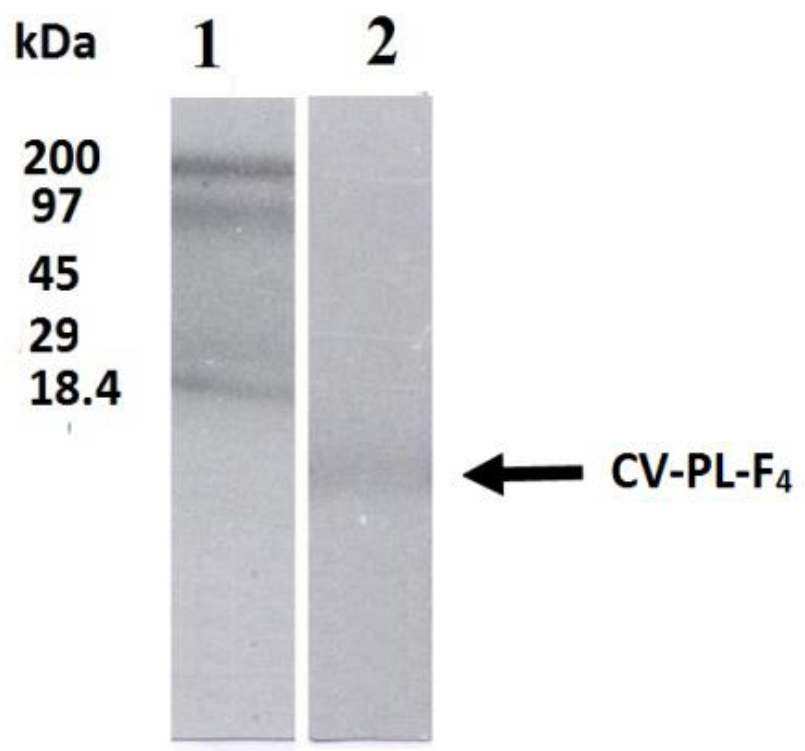

Figure 2: SDS polyacrylamide gel electrophoresis of CV-PL-F4 myotoxin of Cerastes vipera venom. Polyacrylamide gels (12\%) were run using Bio/ PhoresisTM unit (Bio Gene Limited, England). Protein bands were detected by Coomassie brilliant blue R-250. Lane1 contain $\beta$-lactoglobulin $(18,400)$, carbonic anhydrase $(29,000)$, ovalbumin $(45,000)$, phosphorylase b $(97,000)$ and myosin $\mathrm{H}$-chain $(200,000)$ as molecular weight markers. Lane 2: contains CV-PL-F4 myotoxin.

Statistical analysis: The significance of the differences between the means of two experimental groups was determined by the Student's t-test. In some cases, the correlation coefficient between two sets of data was analyzed using one-way analysis of variance [29]. Values of $\mathrm{P}<0.05$ were considered statistically significant.

\section{Results}

\section{Fractionation of Cerastes vipera venom}

The fractionation of the crude Cerastes vipera venom showed ten fractions on Sephadex G-75 (Figure 1). The percentage of the yield of these fractions is shown in (Table 1). The first fraction was the greatest yield isolated toxin (34.5\%) of the venom while the higher protein content was recorded in the third isolated fraction $(818.3$ $\mathrm{mg} / \mathrm{g}$ ). The hemolytic activity of the eluents of the venom after gel filtration appeared in fractions from the third to the tenth fraction. Fraction $4\left(\mathrm{CV}-\mathrm{PL}-\mathrm{F}_{4}\right)$ had the highest PLA 2 (Figure 1), the highest percentage increase in the rate of serum CK release (Table 1) and the highest proteolytic activities (Table 2).

Characterization of a phospholipase $\mathrm{A}_{2}$ fraction $\left(\mathrm{CV}-\mathrm{PL}-\mathrm{F}_{4}\right)$ isolated from Cerastes vipera venom

Analysis of CV-PL- ${ }_{4}$ fraction with SDS-PAGE under reducing conditions showed the presence of a single band (Figure 2). The M.W. of this protein fraction was estimated to be 14,600 . When mice were i.m. injected with $30 \mu \mathrm{g} / 25 \mathrm{~g}$ of the CV-PL-F , they did not show any neurotoxic symptoms such as convulsions, respiratory distress or

Table 1: Protein content of Cerastes vipera venom and isolated fractions and the release of CK.

\begin{tabular}{|c|l|l|l|}
\hline & Protein * & Yield (\%) & $\begin{array}{l}\text { \% increase in the rate of } \\
\text { serum CK release }\end{array}$ \\
\hline Crude venom & 927.81 & & 255 \\
\hline Fractions & & & \\
\hline 2 & 379.6 & 34.5 & 97 \\
\hline 3 & 818.3 & 2.2 & 55 \\
\hline 4 & 214.8 & 18.3 & 88 \\
\hline 5 & 128.8 & 2.5 & 175 \\
\hline 6 & 53.6 & 6.6 & 92 \\
\hline 7 & 84.2 & 2.7 & 91 \\
\hline 8 & 52.4 & 6.7 & 108 \\
\hline 9 & 13.8 & 13.5 & 94 \\
\hline 10 & 55.4 & 3.5 & 54 \\
\hline
\end{tabular}

* Protein content is expressed as $\mathrm{mg}$ protein $/ \mathrm{g}$ venom or fraction.

$\%$ of weight of each fraction in comparison with the total crude venom weight fractionated by gel filtration.

@ Percent of serum CK release after $3 \mathrm{hr}$ of i.m. injection of $15 \mu \mathrm{g}$ venom / 25 $\mathrm{g}$ mouse or $50 \mu \mathrm{g}$ CV-PL- $\mathrm{F}_{4}$ myotoxin in comparison with the control serum $\mathrm{CK}$ activity; $411.9 \pm 48.6 \mathrm{U} / \mathrm{L}$ (Mean $\pm \mathrm{SD}$ ).

Table 2: Biochemical and biological properties of the CV-PL-F fraction isolated from Cerastes vipera venom.

\begin{tabular}{|c|c|}
\hline CV-PL-F ${ }_{4}$ & Property \\
\hline 14600 & - Molecular weight \\
\hline- & - Lethality \\
\hline 48 & - Survival time (hr) \\
\hline $1.78 \pm 0.21$ & - Proteolytic activity $\left(\mathrm{D} \mathrm{A}_{750} / 3 \mathrm{~min} / \mathrm{mg}\right)$ \\
\hline 23.15 ๆ & - Protein yield (\%) \\
\hline 0.014 & $\begin{array}{l}\text { - Phospholipase } A_{2} \text { activity }\left(D A_{925} / 10\right. \\
\text { min) }\end{array}$ \\
\hline$+($ in muscle and lung) & - Hemorrhagic activity \\
\hline- & - Neurotoxicity \\
\hline
\end{tabular}

Cerastes vipera venom. 
Citation: Abd El - Aal A, Abd El-Ghffar EA, Soliman MM. Isolation and Characterization of a Myotoxic Fraction from Cerastes Vipera Snake Venom J Toxins. 2017;4(1): 9

3A)

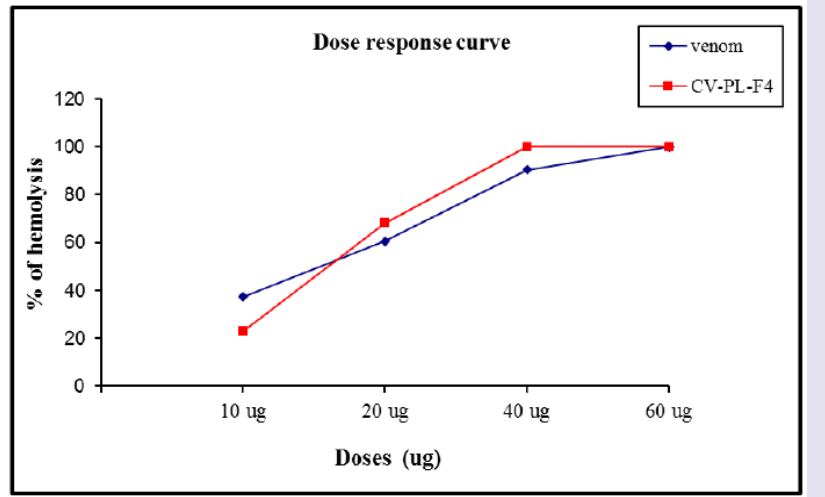

3B)

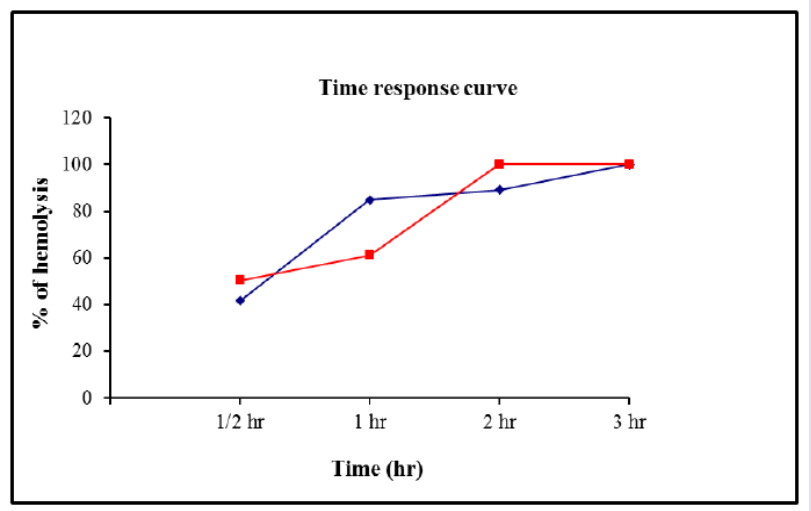

Figure 3: Effect of doses (A) and time (B) of Cerastes vipera venom and CV$\mathrm{PL}-\mathrm{F}_{4}$ myotoxin on the indirect hemolysis of rabbit erythrocytes. Each value represents the mean of three determinations $(n=3)$.

death. When the injection of CV-PL-F $F_{4}$ was increased up to $150 \mu \mathrm{g} / 25$ $\mathrm{g}$, none of the mice showed any neurotoxic symptoms, nor did any mice die within 24,48 or $72 \mathrm{hr}$ of the injection. Thus, the toxin does not appear to be highly lethal. CV-PL- $\mathrm{F}_{4}$ fraction showed caseinolytic activity (Table 2). The protein content of this fraction was 214.8 $\mathrm{mg} / \mathrm{g}$ (23.15\% of the crude venom protein). At the site of CV-PL-F injection, a hemorrhagic spot was observed on the inner surface of the skin and the outer surface of the gastrocnemius muscle "data not shown". The electrophoretic pattern of Cerastes vipera venom showed nine bands with mol. wt. ranging from 1,406 to 180,360

\section{Hemolytic activity of the crude venom and CV-PL-F $\mathrm{F}_{4}$}

The increasing effects of doses or time for the crude venom or CV-PL- $\mathrm{F}_{4}$ were examined. Hemolysis induced by the viper venom ( $\mathrm{r}$ $=0.962)$ and the myotoxin $(\mathrm{r}=0.879)$ fraction was dose dependent (Figure 3). The doses of the venom and CV-PL-F causing 50\% hemolysis (UH50) were 14.69 and $16.77 \mu \mathrm{g}$. The Hemolytic activity of the venom $(r=0.831)$ and CV-PL-F ${ }_{4}(r=0.929)$ were also time dependent.

\section{Myotoxicity of Cerastes vipera venom and CV-PL-F4}

The release of serum CK was significantly $(\mathrm{P}<0.01)$ increased after 1 and $3 \mathrm{hr}$ of Cerastes vipera venom injection, but the enzyme activity after $24 \mathrm{hr}$ was less than $(\mathrm{P}<0.05)$ the released after 1 and $3 \mathrm{hr}$. Figure
4A Shows the myonecrosis induced by i.m. injection of $10 \mu \mathrm{g}$ venom/ $25 \mathrm{~g}$ mice using the myonecrotic index which includes all damaged cells (Figure 5). The presence of the necrotic muscle fibers and vacuolated fibers were used to estimate the amount of myonecrosis

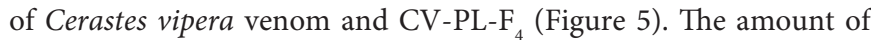
myonecrosis of Cerastes vipera venom was observed (Figure 6) after 1 $\mathrm{hr}(50 \%), 3 \mathrm{hr}(56 \%)$ and $24 \mathrm{hr}$ (59\%). Figure 4B shows that serum CK released following i.m. injection of $30 \mu \mathrm{g}$ CV-PL-F $\mathrm{F}_{4}$ was significantly increased by $153 \%(\mathrm{P}<0.05)$ after $1 \mathrm{hr}, 178 \%(\mathrm{P}<0.01)$ after $3 \mathrm{hr}$ and $195 \%(\mathrm{P}<0.01)$ after $24 \mathrm{hr}$. The myonecrotic index induced by CVPL- $\mathrm{F}_{4}$ was increased by $56 \%, 61 \%$ and $61 \%$ after 1,3 and $24 \mathrm{hr}$ of the fraction injection respectively (Figure 6).

Antimyotoxic effects of vitamins E and $\mathrm{C}$, dexamethasone and trypsin

Dexamethasone or Vit (E or C) or trypsin was mixed with Cerastes vipera venom injection into mice, serum CK activity was significantly decreased $(\mathrm{P}<0.05-0.01)$ compared with the venomtreated group but it was similar to those observed in control mice, indicating a complete inhibition of the $\mathrm{CK}$ release following venom injection (Figure 7A). Myonecrotic index of Cerastes vipera venom in mice treated with $\mathrm{Vit} \mathrm{E}$ was decreased by $49 \%$ in comparison with that of mice treated only with the venom (Figure 8 ). This antimyonecrotic effect was higher on using Vit C (26\% necrosis) in comparison with the necrotic effect of the venom. Also, dexamethasone and trypsin decreased the myonecrotic index of the venom to $34 \%$ and $36 \%$ respectively (Figure 8). Injection of a mixture of CV-PL-F and Vit E showed complete inhibition of serum CK release. This effect was not similar when Vit C was injected instead of Vit E. Vit C partially (45\%) antagonized the release of CK following injection of CV-PL-F ${ }_{4}$. Dexamethasone and trypsin could abolish the ability of CV-PL- $\mathrm{F}_{4}$ to

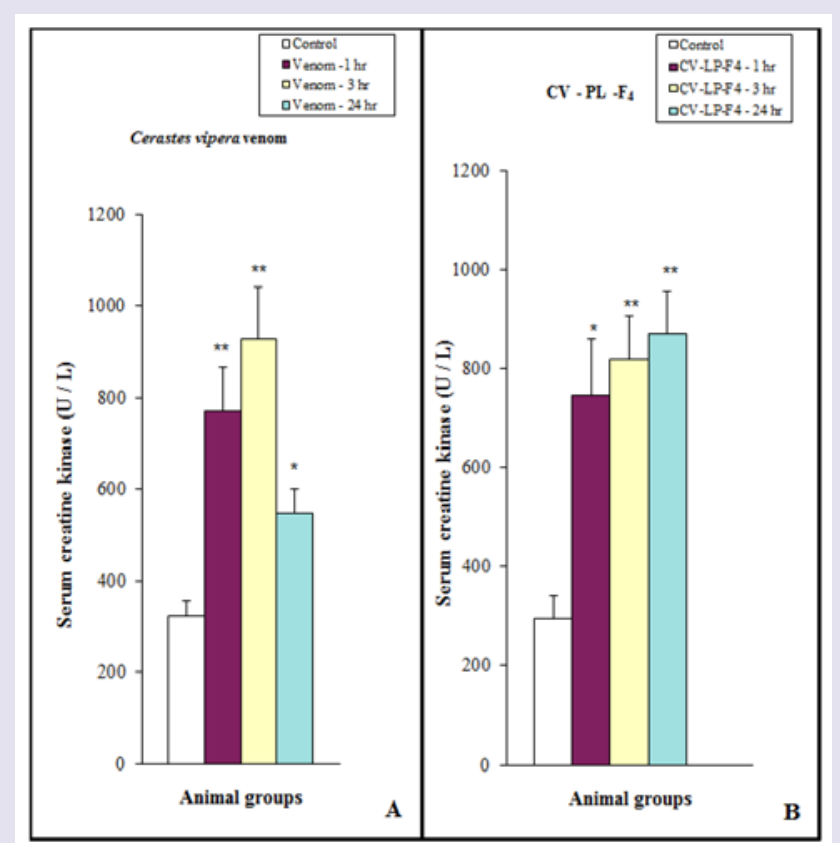

Figure 4: Effect of Cerastes vipera venom (A) and CV-PL- $\mathrm{F}_{4}$ myotoxin (B) on serum creatine kinase release in mice. Each value represents mean \pm S.E. $\mathrm{n}=8 ;{ }^{*} \mathrm{P}<0.05 ;{ }^{* *} \mathrm{P}<0.01$. 
Citation: Abd El - Aal A, Abd El-Ghffar EA, Soliman MM. Isolation and Characterization of a Myotoxic Fraction from Cerastes Vipera Snake Venom J Toxins. 2017;4(1): 9

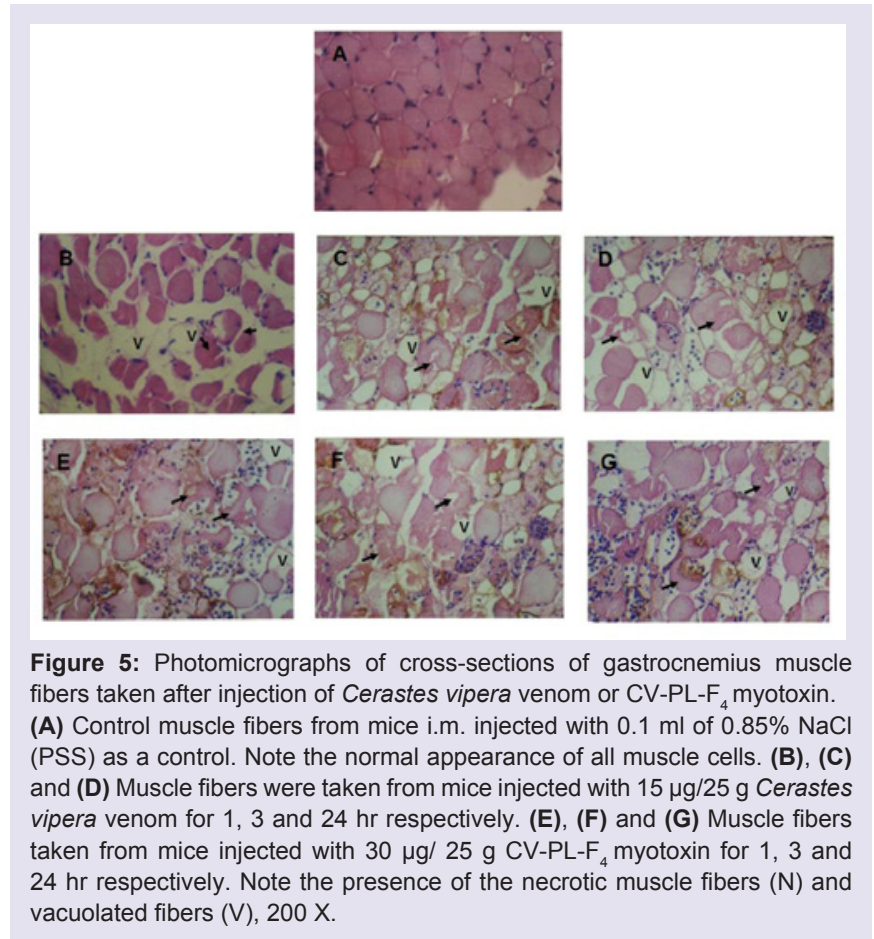

release of CK from muscles (Figure 7B). Dexamethasone, Vit E and C, and trypsin abolished the myonecrosis of CV-PL- $\mathrm{F}_{4}$ by decreasing the myonecrotic index to $34,40,31$, and $24 \%$ respectively in comparison to the levels induced by CV-PL- $\mathrm{F}_{4}$ only (Figure 8).

\section{Effect of Cerastes vipera venom and CV-PL-F4 on serum creatinine level}

As shown in (Figure 9A), injection of Cerastes vipera venom (10 $\mu \mathrm{g} / 25 \mathrm{~g}$ mice) or CV-PL-F 4 (30 $\mu \mathrm{g} / 25 \mathrm{~g}$ mice) induced a significant increase in serum creatinine during the experimental periods. While animals treated with the venom for $1 \mathrm{hr}$ did not show any significant effect. On using Vit E, serum creatinine level of mice treated with the viper venom was comparable to that of the control mice (Figure 9A). Dexamethasone, Vit C, and trypsin failed to counterbalance the increase in serum creatinine of mice treated with the viper venom. In animals treated with CV-PL-F , only trypsin was able to decrease the high level of serum creatinine induced by the venom fraction (Figure 9B). Dexamethasone, Vit E, and C did not decrease the inductive effect of CV-PL-F $\mathrm{F}_{4}$ to increase the serum creatinine levels.

\section{Discussion}

The present results showed that ten fractions were isolated from Cerastes vipera venom. Eight fractions (from the third to the tenth fraction) with PLA ${ }_{2}$ activity and two fractions (the first and the second fraction) without $\mathrm{PLA}_{2}$ activity. The first and third peaks have the highest yield isolated toxin and protein content, respectively. The fourth peak (CV-PL-F $)$ has the highest $\mathrm{PLA}_{2}$ and proteolytic activities causing the most highly myotoxic fraction. This finding is similar to the observations of Labib et al. who isolated Cerastes vipera venom into 8 fractions and recorded that the first peak has the highest protease activity and lethality causing marked hemorrhages in mice [1]. $\mathrm{PLA}_{2}$ snake venom usually showed indirect hemolytic activity because promotes hydrolysis of lecithins to lysolecithins able to lyse $\mathrm{RBC}$ membranes [30]. The isolated $\mathrm{PLA}_{2}$ from Cerastes vipera venom showed indirect hemolytic activity. The myotoxin CV-PL-F 4 caused a rapid necrosis of skeletal muscles after 1,3 and 24 hours of injection. In addition, CV-PL- $\mathrm{F}_{4}$ has a phospholipase activity when tested on egg yolk phospholipids. The PLA 2 myotoxin of Cerastes vipera venom is similar to other myotoxin isolated from different snake venoms [22,31-34]. This myotoxin has no neurotoxic symptoms or lethal activity in mice injected with $30 \mu \mathrm{g} / 25 \mathrm{~g}$. Examination of CV-PL-F using SDS-PAGE electrophoresis revealed that the fraction appeared to be almost pure. The myotoxin CV-PL-F has M.W of about 14,600. Phospholipases $\mathrm{A}_{2}$ molecular mass range from 13 to $19 \mathrm{kDa}$ [35] and typically requires $\mathrm{Ca}^{2+}$ at for their catalytic activity [36]. PLA isolated from snake venoms are much less lethal than neurotoxins [17,37-39]. Some of these toxins exhibited myotoxic activity in vivo [38,40-43]. Some of the myotoxic PLA, have high enzymatic activity, whereas others lack or have an extremely low catalytic activity. However, a myotoxin was isolated by Gutierrez et al. from the venom of the snake; Bothrops nummifer with M.W of 16,000 which lacked PLA activity and induced skeletal muscle damage [44]. On the other hand, Diaz et al. isolated a myotoxic protein fraction from the venom of Bothrops asper snake with PLA 2 activity and induced acute muscle damage in mice [32]. This indicates that myotoxins may have or have no PLA ${ }_{2}$ activity. The myonecrosis induced by the crude venom and CV-PL- $\mathrm{F}_{4}$ may be a result of the progressive loss of integrity of the sarcolemma due to the hydrolysis of phospholipids. This is supported by the hemolytic effect of the venom and CV-PL- $\mathrm{F}_{4}$ on rabbit $\mathrm{RBC}$ membrane in vitro. Also, the interaction of the fraction with muscle

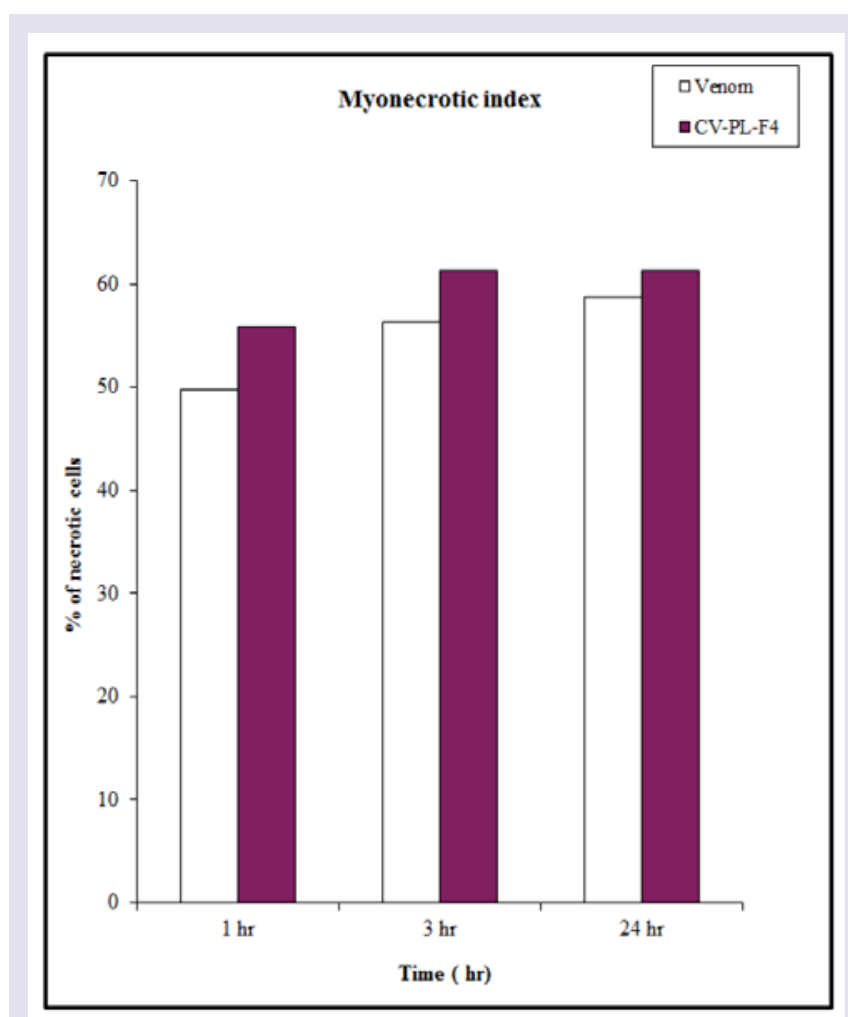

Figure 6: Percentage of myonecrotic cells induced by Cerastes vipera and CV-PL-F ${ }_{4}$ myotoxin. 


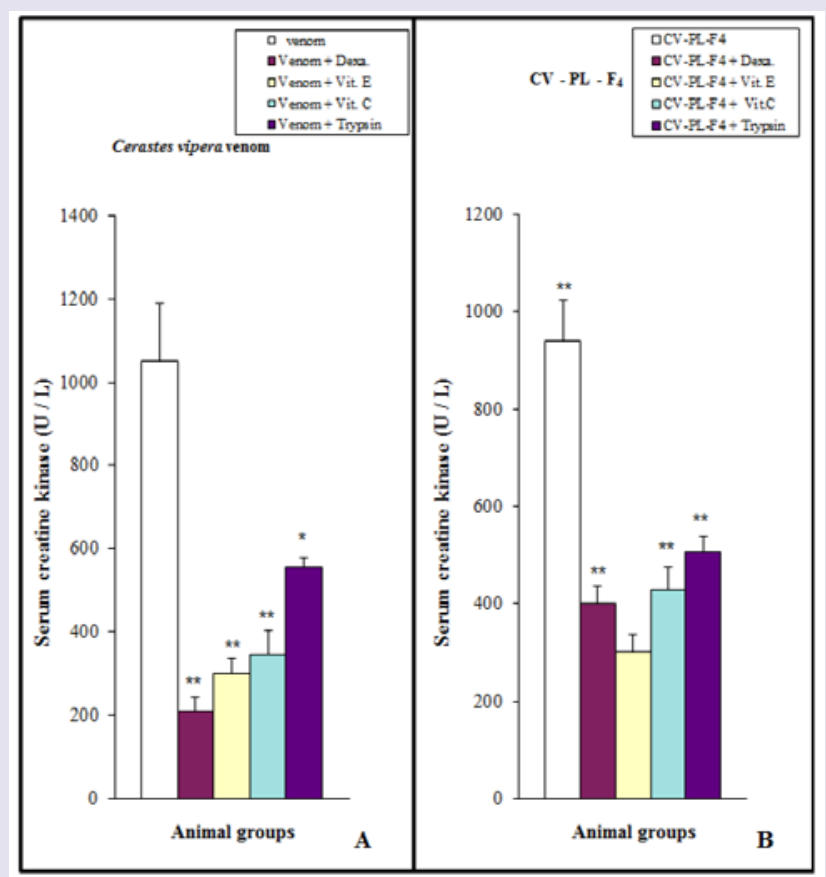

Figure 7: Effect of dexamethasone (Dexa) and vitamins E (Vit. E) and C (Vit. C) and trypsin on creatine kinase release after the injection of Cerastes vipera venom $(\mathrm{A})$ and $\mathrm{CV}-\mathrm{PL}-\mathrm{F}_{4}$ myotoxin $(\mathrm{B})$.

Significant differences were compared to the value of venom- or CV-PL-F treated mice alone in case of (A) and (B) Each value represents mean \pm S.E., $n=8 ;{ }^{*} \mathrm{P}<0.05 ;{ }^{* *} \mathrm{P}<0.01$.

membrane integrity induced muscle damage mediated by a number of events such as calcium influx and efflux of cytosolic molecules $[45,46]$. Snake venoms belonging to Viperidae are known to possess a high content of proteinase [47]. Cerastes vipera venom (after $3 \mathrm{hr}$ ) and CV-PL- $\mathrm{F}_{4}$ (after $24 \mathrm{hr}$ ) induced highest CK release in serum and resulted in extensive muscle tissue damage. Huancahuire-Vega et al. recorded a high CK level 3- $6 \mathrm{hr}$ after i.m. injection of Bothrops asper venom in mice [48]. Tissue damage shows an increase of CK levels in serum since this enzyme is abundant in the cytosol of skeletal muscle fibers [49]. This finding suggests that the plasmatic membrane of these cells has rapidly lost its ability to regulate the permeability to this enzyme [50]. Such alterations are similar to those generated by venom that results in muscular necrosis [37,51]. The results suggest a correlation between the serum levels of $\mathrm{CK}$ and the myonecrosis as demonstrated by the myonecrotic index. These findings are similar to other studies on the myotoxic effects of Bothrops venoms [31] and South American rattlesnake; Crotalus durissus terrificus by Gopalakrishnakone et al. and Azevedo-Marquoes et al. [52,53]. The degenerative change in the structure of murine skeletal muscle induced by i.m. injection of phospholipase $\mathrm{A}_{2}$ fraction isolated from Crotalus durissus terrificus which was attributed to the hydrolysis of sarcolemma membrane [54]. The myonecrosis observed in the present study was also supported by higher serum creatinine, which resulted from the conversion of creatine [55]. CV-PL-F $\mathrm{F}_{4}$ did not produce visible myoglobinuria as previously observed in other snake myotoxins $[38,52,56,57]$. Anderson and Ownby observed severe hemorrhage and necrosis of some skeletal muscle cells in mice i.m. injected with a proteinase $\mathrm{H}$ fraction isolated from eastern diamondback rattlesnake (Crotalus adamonteus) [58]. Moreover, there is a direct correlation between serum CK release and muscle damage (myonecrotic index) caused by the Cerastes vipera venom and CV-PL- $\mathrm{F}_{4}$ myotoxin $(\mathrm{r}=0.77$ and 0.99 respectively). Clinical studies of myonecrosis, in severe cases of envenoming, have described a generally limited effectiveness of antivenom serotherapy in preventing the development of local tissue damage [59]. Moreover, Gay et al. demonstrated that the hemorrhagic activity of the viper Bothrops alternatus was neutralized by anti-baltergin IgG antibodies, but the myonecrotic activity was not ameliorated by this antiserum [15]. Therefore, the use of dexamethasone, Vit $\mathrm{E}$ and $\mathrm{C}$ as a treatment for envenomation may be more effective than serotherapy. It was found that the myotoxicity of the crude venom and CV-PL-F myotoxin was completely inhibited by dexamethasone. The present results suggested that dexamethasone with its anti-inflammatory property may ameliorate the muscle damage resulted from crude venom and CV-PL- $\mathrm{F}_{4}$ myotoxin. This suggestion was supported by the decreased CK of the present study. These findings are concomitant with the study of Patrão -Neto et al. showing that dexamethasone ameliorated the inflammation and myotoxicity induced by Bothrops venom [60]. Also, Vit $\mathrm{E}$ and $\mathrm{C}$ reduced the $\mathrm{CK}$ released to approximately the control levels in mice treated with the crude venom and CV-PL-F. Dexamethasone, Vit E and C and trypsin reduced the myonecrotic index induced by the crude venom and CV-PL- $\mathrm{F}_{4}$. The mode of action of myotoxic PLA 2 has been thoroughly discussed by Gutiérrez et al. [56]. There exists some evidence that the enzymatic properties of these myotoxins are involved in the necrosis. It may be due to the release of lysolecithin in vivo $[34,48,56]$ and hydrolysis of phospholipids in muscle cells. This explanation is supported by the study of the effect of the venom and CV-PL- $\mathrm{F}_{4}$ myotoxin on the integrity of the cell membrane of rabbit erythrocytes. Cerastes vipera

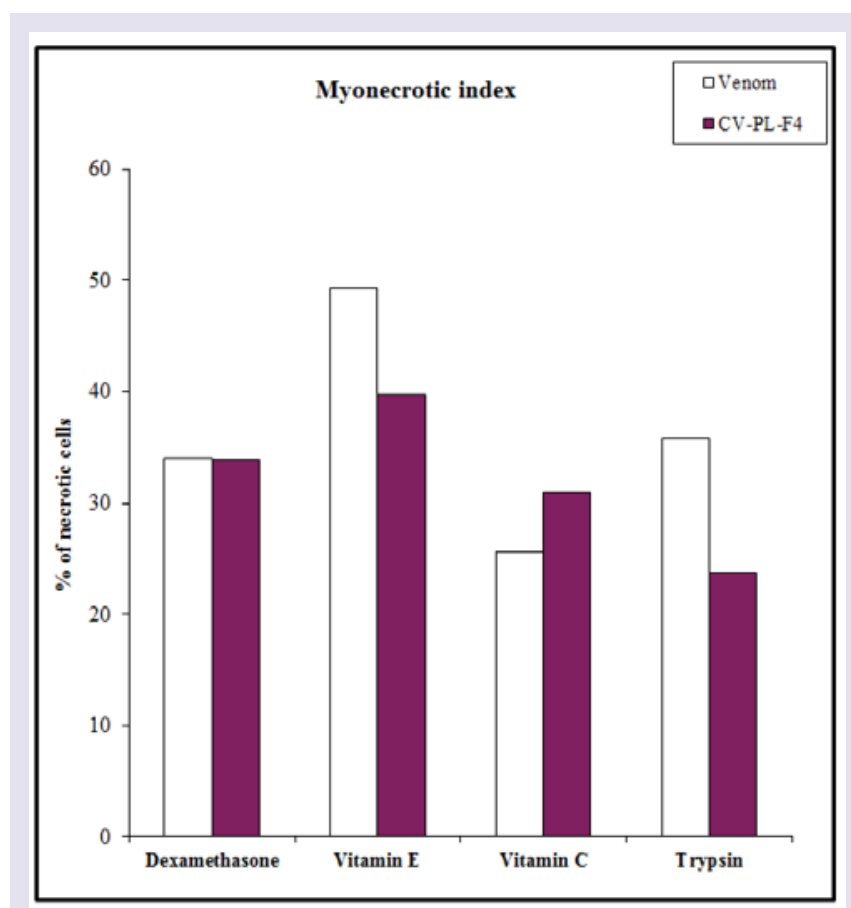

Figure 8: Antagonism of the myonecrosis induced by Cerastes vipera venom and $\mathrm{CV}-\mathrm{PL}-\mathrm{F}_{4}$ myotoxin using dexamethasone, vitamins $\mathrm{E}$ and $\mathrm{C}$ and trypsin. 


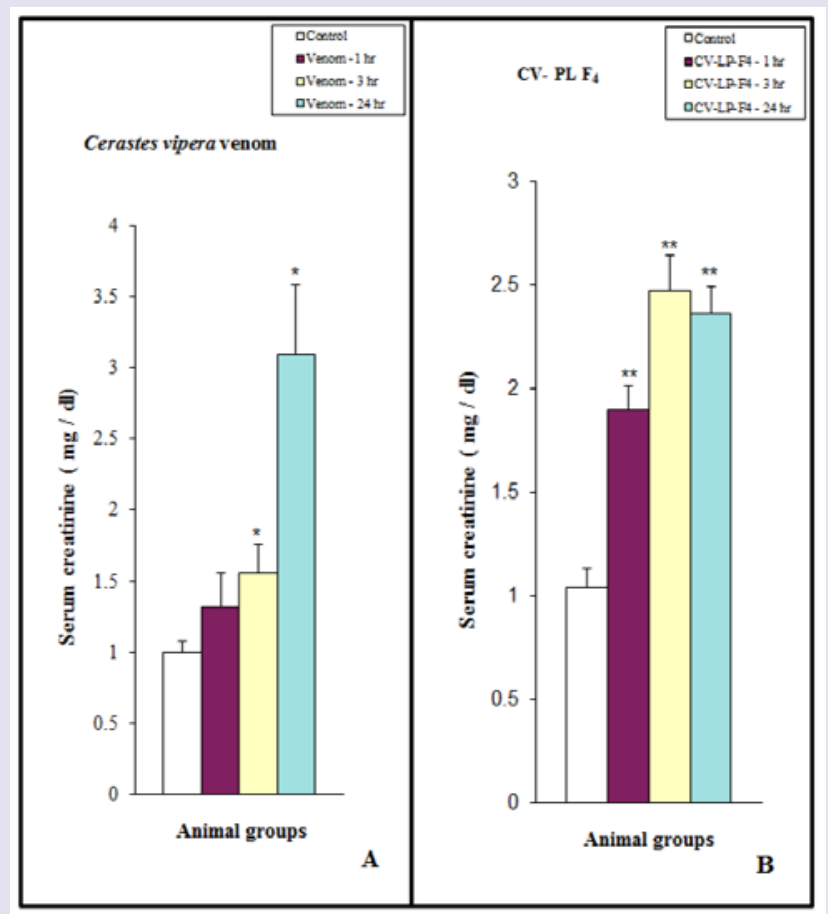

Figure 9: Effect of Cerastes vipera venom (A) and CV-PL- $\mathrm{F}_{4}$ myotoxin (B) on serum creatinine in mice. Each value represents mean \pm S.E., $n=8$ * $P$ $<0.05 ; \quad{ }^{* *} \mathrm{P}<0.01$

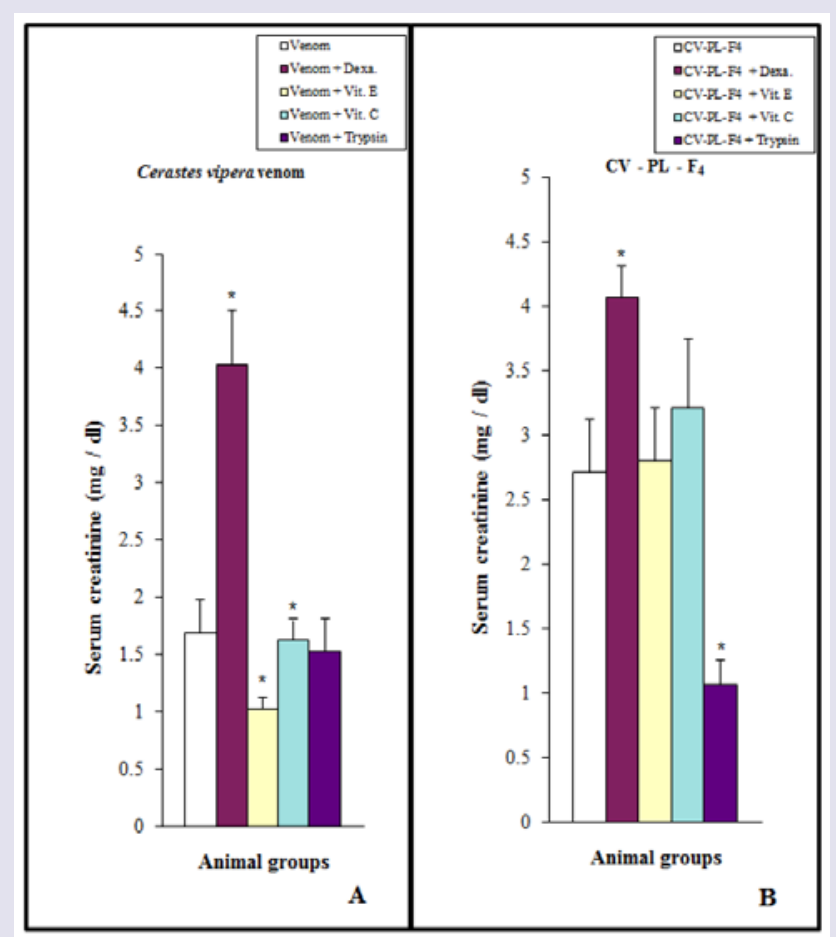

Figure 10: Effect of dexamethasone (Dexa) and vitamins $E$ (Vit. E) and C (Vit. C) and trypsin on serum creatinine after the injection of Cerastes vipera venom (A) and CV-PL- $\mathrm{F}_{4}$ myotoxin (B).

Significant differences were compared to the value of venom-or CV-PL- $\mathrm{F}_{4}-$ treated mice alone in case of $(A)$ and $(B)$ Each value represents mean \pm

S.E., $n=8 * \mathrm{P}<0.05$. and its myotoxin hydrolyzed the plasma membrane of rabbit RBCs in vitro. This assumption is concomitant with the interpretation of Harris and MacDonnell and Gutiérrez et al. [56,61]. These authors showed alterations of plasma membrane integrity and a general increase in membrane permeability, causing an influx of ions such as calcium, which may also trigger intrinsic mechanisms leading to cell death and necrotic events. The hemolytic activity of the venom of the viper; Cerastes vipera and the isolated myotoxin (CV-PL-F $\left.{ }_{4}\right)$ appear to be dependent on their phospholipase $\mathrm{A}_{2}$ activity as recorded in several studies of other snake venoms $[2,62,63]$. Vit $E$, as an antioxidant present in membranes, confers stability to the membrane $[64,65]$. Recently, it was reported the stabilization of lysosomal membranes by Vit $\mathrm{E}$ against damage may be inflicted by viper venom PLA $_{2}$ [66]. Thus, Vit E partially inhibited the lysis of the plasma membrane and fatty acid release (phospholipid splitting) caused by snake venoms. It seems reasonable to conclude that tocopherol protects cell membrane against the hydrolytic action of the viper venoms. Lysolecithins, products of exogenous phospholipid hydrolysis, cause considerable damage to the cell membranes by venoms and PLA. This interpretation was supported by the assessment of the indirect hemolytic activity of the viper venom and it's CV-PL-F. Jurak and Conde suggested that $\alpha$-tocopherol plays a role in the stabilization of biological membranes. In spite of dexamethasone and Vit E decreased significantly the CK released from the envenomated muscle, with either crude Cerastes vipera or CV-PL-F ${ }_{4}$, Vit E was more effective as antimyotoxins [67]. Therefore, regular intake of Vit $\mathrm{E}$ might be useful for people living in an area where snakes abound. The crude venom and CV-PL- $\mathrm{F}_{4}$ myotoxin had proteases activity that may be responsible for the myonecrosis observed in this study. Many snake venoms especially belonging to the vipers and their toxins cause myotoxicity which has been attributed to the presence of proteases or phospholipase $A_{2}[33,44]$. These enzymes caused disruption directly the plasma membrane integrity of the muscle cells $[46,68]$. It is possible that the myonecrosis may be caused by the development of ischemia resulting from microvascular alteration of muscle tissue by the viper venom and CVPL-F ${ }_{4}$. Such activity has been previously demonstrated by the action of other viper venoms, which have been shown to contain hemorrhagins in their composition [37]. Hemorrhage was observed on the inner surface of the skin and on the outer surface of the gastrocnemius muscle, in addition to the hemorrhage in the lungs. Myonecrosis appeared only after massive intramuscular hemorrhage due to snake venom injection [69]. Estimation of serum levels of CK together with the histological myonecrosis index, in the present study, may be a real evidence of the necrosis of the muscles following envenomation with crude venom and CV-PL- $\mathrm{F}_{4}$ myotoxin (Figure 10). This is because the quantitative assessment of muscle damage by the estimation of the serum levels of CK only is not valid. The estimation of serum level of CK and the myonecrotic index could be supportive to each other as an indication of myonecrosis. Moreover, dexamethasone and Vit $\mathrm{E}$ have ameliorative effect for the myotoxic effect of the crude Cerastes vipera venom and the fraction CV-PL-F.

\section{Conclusion}

The present study supports the hypothesis that the isolated phospholipase $\mathrm{A}_{2}$ (CV-PL-F $)$ by Sephadex G-75 exhibited high myotoxic activity, demonstrating its capacity to contribute to tissue 
Citation: Abd El - Aal A, Abd El-Ghffar EA, Soliman MM. Isolation and Characterization of a Myotoxic Fraction from Cerastes Vipera Snake Venom J Toxins. 2017;4(1): 9

damage after snakebite or envenoming produced by this Cerastes vipera snake. This topic needs further investigation and will be considered in the future. On the other hand, dexamethasone and Vit E were more effective in alleviating the myotoxic effect of the crude Cerastes vipera venom and its fraction $\left(\mathrm{CV}-\mathrm{PL}-\mathrm{F}_{4}\right)$. Therefore, it may be more beneficial if the dose increased in future studies.

\section{References}

1. Labib RS, Halim HY, Farag NW (1979) Fractionation of Cerastes cerastes and Cerastes vipera snake venoms by gel filtration and identification of some enzymatic and biological activities. Toxicon 17: 337-345.

2. Laraba-Djebari F, Martin-Eauclaire MF (1990) Purification and characterization of $\mathrm{PLA}_{2}$ from viper snake venom. Toxicon 28: 637-647.

3. Labib RS, Awad ER, Farag NW (1981) Proteases of Cerastes cerastes (Egyptian sand viper) and Cerastes vipera (Sahara sand viper) snake venoms. Toxicon 19: 73-83.

4. Daoud EW, Halim HY, Shaban EA, el-Asmar MF (1987) Further characterization of the anticoagulant proteinase, cerastase F-4 from Cerastes cerastes (Egyptian sand viper) venom. Toxicon 25: 891-897.

5. Kini RM, Iwanaga S (1986) Structure-function relationships of phospholipases I: Prediction of presynaptic neurotoxicity. Toxicon 24: 527-541.

6. Otero R, Gutiérrez J, Beatriz MM, Duque E, Rodríguez O, et al. (2002) Complications of Bothrops, Porthidium, and Bothriechis snakebites in Colombia. A clinical and epidemiological study of 39 cases attended in a university hospital. Toxicon 40: 1107-1114.

7. Warrell DA (2004) Epidemiology, clinical features and management of snake bites in Central and South America. In: Campbell J, Lamar WW (Eds), Venomous reptiles of the Western Hemisphere. Cornell University Press, Ithaca, pp. 709-761.

8. Mukherjee AK, Ghosal SK, Maity CR (2000) Some biochemical properties of Russell's Viper (Daboia russelli) venom from Eastern India: correlation with clinical pathological manifestation in Russell's Viper bite. Toxicon 38: 163175.

9. Vishwanath BS, Kini RM, Gowda TV (1988) Purification and partial biochemical characterization of an edema inducing phospholipase $A_{2}$ from Vipera russelli (Russell's viper) snake venom. Toxicon 26: 713-720.

10. Condrea E, Yang CC, Rosenberg P (1980) Comparison of a relatively toxic phospholipase $A_{2}$ from Naja nigricollis snake venom with that of a relatively non-toxic phospholipase $A_{2}$ from Hemachatus hemachatus snake venom- I. Enzymatic activity on free and membrane bound substrates. Biochem Pharmacol 29: 1555-1563.

11. Schneemann M, Cathomas R, Laidlaw ST, El Nahas AM, Theakston RD et al. (2004) Life-threatening envenoming by the Saharan horned viper (Cerastes cerastes) causing micro-angiopathic haemolysis, coagulopathy and acute renal failure: clinical cases and review. QJM 97: 717-727.

12. Keyler DE (2008) Envenomation by the lowland viper (Proatheris superciliaris): Severe case profile documentation. Toxicon 52: 836-841.

13. Ownby CL, Colberg TR, White SP (1997) Isolation, characterization and crystallization of a phospholipase $A_{2}$ myotoxin from the venom of the prairie rattlesnake (Crotalus viridis viridis). Toxicon 35: 111-124.

14. Melo PA, Ownby CL (1999) Ability of wedelolactone, heparin, and parabromophenacyl bromide to antagonize the myotoxic effects of two crotaline venoms and their PLA $_{2}$ myotoxins. Toxicon 37: 199-215.

15. Gay C, Maruñak S, Teibler P, Leiva L, Acosta O (2013) Effect of monospecific antibodies against baltergin in myotoxicity induced by Bothrops alternatus venom from northeast of Argentina. Role of metalloproteinases in muscle damage. Toxicon 63: 104-111.

16. Zouari-Kessentini R, Luis J, Karray A, Kallech-Ziri O, Srairi-Abid N, et al (2009) Two purified and characterized phospholipases $A_{2}$ from Cerastes cerastes venom, that inhibit cancerous cell adhesion and migration. Toxicon 53: 444-453.
17. Saikia D, Majumdar S, Mukherjee AK (2013) Mechanism of in vivo anticoagulant and haemolytic activity by a neutral phospholipase $A(2)$ purified from Daboia russelii russelii venom: Correlation with clinical manifestations in Russell's Viper envenomed patients. Toxicon 76: 291-300.

18. Spawls S, Branch B (1995) The Dangerous Snakes of Africa. Ralph Curtis Books. Dubai: oriental press, pp. 192.

19. Mallow D, Ludwig D, Nilson G (2003) True vipers: natural history and toxinology of old world vipers. Krieger Publishing Company, pp 359.

20. Meier J, Banks B, Creppy EE, Habermehi G, Kornalik F, et al. (1993) Ethical standards for animal experiments in toxinological research. Toxicon 31: 9-12.

21. Gutiérrez JM, Ávila C, Rojas E, Cerdas L (1988) Alternative in vitro method for testing the potency of the polyvalent antivenom produced in Costa Rica. Toxicon 26: 411-413.

22. Rodrigues RS, Izidoro LF, Teixeira SS, Silveira LB, Hamaguchi A, et al. (2007) Isolation and functional characterization of a new myotoxic acidic phospholipase $A(2)$ from Bothrops pauloensis snake venom. Toxicon 50: 153-165.

23. Joubert FJ, Taljaard N (1980) Purification, some properties and aminoacid sequences of two phospholipases A (CM-II and CM-III) from Naja naja kaouthia venom. Eur J Biochem 112: 493-499.

24. Lowry OH, Rosenbrough NJ, Farr AL, Randall RJ (1951) Protein measurement with the Folin phenol reagent. J Biol Chem 193: 265-275.

25. Mandelbaum FR, Reicher AP, Assakura MT (1982) Isolation and characterization of a proteolytic enzyme from the venom of the snake Bothrops jararaca (jararaca). Toxicon 20: 955-972.

26. Meier J, Theakston RD (1986) Approximate LD50 determination of snake venoms using eight to ten experimental animals. Toxicon 24: 395-401.

27. Szasz G, Gruber W, Bernt E (1976) Creatine kinase in serum: 1. Determination of optimum reaction conditions. Clin Chem 22: 650-656.

28. Annino JS, Giese RW (1979) Clinical chemistry, $4^{\text {th }}$ Eds. Little Brown, Boston, pp. $170-177$

29. Campbell RC (1994) Statistics for biologist. Cambridge University Press.

30. Ketelhut DF, de Mello MH, Veronese EL, Esmeraldino LE, Murakami MT, et al. (2003) Isolation, characterization and biological activity of acidic phospholipase A2 isoforms from Bothrops jararacussu snake venom. Biochimie 85: 983-991.

31. Moura-da-Silva AM, Desmond H, Laing G, Theakston RD (1991) Isolation and comparison of myotoxins isolated from venoms of different species of Bothrops snakes. Toxicon 29: 713-723.

32. Diaz C, Lomonte B, Zamudio F, Gutierrez JM (1995) Purification and characterization of myotoxin IV, a phospholipase A2 variant, from Bothrops asper snake venom. Nat Toxins 3: 26-31.

33. Warrell DA (1995) Clinical Toxicology of Snakebite in Africa and the Middle East / Arabian Peninsula. In: Meier J, White J. (Eds). Handbook of Clinical Toxicology of Animal venoms and Poisons. CRC Press. Boca Raton. pp. 493594.

34. Soares AM, Rodrigues VM, Homsi-Brandeburgo MI, Toyama MH, Lombardi $\mathrm{FR}$, et al. (1998) A rapid procedure for the isolation of the Lys-49 myotoxin II from Bothrops moojeni (caissaca) venom: Biochemical characterization, crystallization, myotoxic and edematogenic activity. Toxicon 36: 503-514

35. Schaloske RH, Dennis EA (2006) The phospholipase A2 superfamily and its group numbering system. Biochim Biophys Acta 1761: 1246-1259.

36. Romero-Vargas FF, Rocha T, Cruz-Höfling AM, Rodrigues-Simioni L, PonceSoto LA, et al. (2014) Biochemical Characterization of a PLA2 Btae TX-I Isolated from Bothriopsis taeniata Snake Venom: A Pharmacological and Morphological Study. J Clin Toxicol 4: 3.

37. Gutiérrez JM, Lomonte B (1995) Review article: Phospholipase A2 myotoxins from Bothrops snake venoms. Toxicon 33: 1405-1424.

38. Harris JB (1991) Phospholipases in snake venoms and their effects on nerve 
Citation: Abd El - Aal A, Abd El-Ghffar EA, Soliman MM. Isolation and Characterization of a Myotoxic Fraction from Cerastes Vipera Snake Venom J Toxins. 2017;4(1): 9

ISSN: $2328-1723$

and muscle. In: Harvey AL (Edn). Snake Toxins. Pergamon Press, New York pp. 91-129.

39. Doley R, Mukherjee AK (2003) Purification and characterization of an anticoagulant phospholipase A2 from Indian monocle cobra (Naja kaouthia) venom. Toxicon 41: 81-91.

40. Mebs D, Ownby CL (1990) Myotoxic components of snake venoms: their biochemical and biological activities. Pharmacol Ther 48: 223-236.

41. Lomonte B, Tarkowski A, Hanson LA (1993) Host response to bothrops asper snake venom. Analysis of edema formation, inflammatory cells, and cytokine release in a mouse model. Inflammation 17: 93-105.

42. Johnson EK, Ownby CL (1994) The role of extracellular ions in the pathogenesis of myonecrosis induced by a myotoxin isolated from broadbanded copperhead (Agkistrodon contortrix laticinctus) venom. Comp Biochem Physiol 107: 359-366.

43. Fuly AL, Calil-Elias S, Martinez AM, Melo PA, Guimarães JA (2003) Myotoxicity induced by an acidic Asp-49 phospholipase $A_{2}$ isolated from Lachesis muta snake venom: Comparison with lysophosphatidylcholine. Int.J Bioche Cell Biol 35: 1470-1481.

44. Gutiérrez JM, Lomonte B, Cerdas L (1986) Isolation and partial characterization of a myotoxin from the venom of the snake Bothrops nummifer. Toxicon 24: 885-894.

45. Kini RM (2003) Excitement ahead: structure, function and mechanism of snake venom phospholipase A2 enzymes. Toxicon 42: 827-840.

46. Montecucco C, Gutierrez JM, Lomonte B (2008) Cellular pathology induced by snake venom phospholipase A2 myotoxins and neurotoxins: common aspects of their mechanisms of action. Cell Mol Life Sci 65: 2897-2912

47. Bazaa A, Marrakchi N, El Ayeb M, Sanz L, Calvete JJ (2005) Snake venomics: comparative analysis of the venom proteomes of the Tunisian snakes Cerastes cerastes, Cerastes vipera and Macrovipera lebetina. Proteomics 5: 4223-4235

48. Huancahuire-Vega S, Ponce-Soto LA, Martins-de-Souza D, Marangoni S (2009) Structural and functional characterization of brazilitoxins II and II (BbTX-II and -III), two myotoxins from the venom of Bothrops brazili snake. Toxicon 54: 818-827.

49. Maruñak SL, Leiva L, Garcia Denegri ME, Teibler P, Acosta De Pérez O (2007) Isolation and biological characterization of a basic phospholipase $A_{2}$ from Bothrops jararacussu snake venom. Biocell 31: 355-364

50. Gutiérrez JM, Núñez J, Díaz C, Cintra AC, Homsi-Brandeburgo MI, et a (1991) Skeletal muscle degeneration and regeneration after injection of bothropstoxin II, a phospholipase A2 isolated from the venom of the snake. Bothrops jararacussu. Exp Mol Pathol 55: 217-229.

51. de Pérez OA, Koscinczuk $P$, Teibler $P$, Negrette $M S$, Teibler $P$, et al. (1998) Actividades hemorrágica y edematizante y alteraciones histológicas en almohadilla plantar de ratón inducidas por veneno de serpientes de los géneros Bothrops y Crotalus de Argentina. Toxicon 36: 1165-1172.

52. Gopalakrishnakone P, Dempster DM, Hawgood BJ, Elder HY (1984) Cellular and mitochondrial changes induced in the structure of murine skeletal muscle by crotoxin, a neurotoxic phospholipase $\mathrm{A}_{2}$, complex. Toxicon 22: 85-98.

53. Azevedo-Marques MM, Cupo P, Coimbra TM, Hering SE, Rossi MA, et al (1985) Myonecrosis, myoglobinuria and acute renal failure induced by South
American rattlesnake (Crotalus durissus terrificus) envenomation in Brazil. Toxicon 23: 631-636.

54. Marchi-Salvador DP, Correa LC, Magro AJ, Oliveira CZ, Soares AM, et al. (2008) Insights into the role of oligomeric state on the biological activities of crotoxin: crystal structure of a tetrameric phospholipase A2 formed by two isoforms of crotoxin B from Crotalus durissus terrificus venom. Proteins 72 : 883-891.

55. Devlin TM (1993) Biochemistry with clinical correlations. New York. John Wiley.

56. Gutiérrez JM, Ownby CL, Odell GV (1984) Isolation of a myotoxin from Bothrops asper venom: partial characterization and action on skeletal muscle. Toxicon 22: 115-128.

57. Ownby CL, Nikai T, Imai K, Sugihara H (1990) Pathogenesis of hemorrhage induced by bilitoxin, a hemorrhagic toxin isolated from the venom of the common cantil (Agkistrodon bilineatus bilineatus). Toxicon 28: 837-846.

58. Anderson SG, Ownby CL (1997) Pathogenesis of hemorrhage induced by proteinase $\mathrm{H}$ from eastern diamondback rattlesnake (Crotalus adamanteus) venom. Toxicon 35: 1291-1300.

59. Cardoso JL, Fan HW, França FO, Jorge MT, Leite RP, et al. (1993) Randomized comparative trial of three antivenoms in the treatment of envenoming by lance-headed vipers (Bothrops jararaca) in Sao Paulo, Brazil. Q J Med 86: 315-325.

60. PatrAo-Neto FC, Tomaz MA, Strauch MA, Monteiro-Machado M, Rocha JR Jr, et al. (2013) Dexamethasone antagonizes the in vivo myotoxic and inflammatory effects of Bothrops venoms. Toxicon 69: 55-64.

61. Harris JB, MacDonell CA (1981) Phospholipase A activity of notexin and its role in muscle damage. Toxicon 19: 419-430.

62. Jiang MS, Fletcher JE, Smith LA (1989) Factors influencing the hemolysis of human erythrocytes by cardiotoxins from Naja naja kaouthia and Naja naja atra venoms and a phospholipase $A_{2}$ with cardiotoxin-like activities from Bungarus fasciatus venom. Toxicon 27: 247-257.

63. Tan NH, Ponnudurai G (1992) A comparative study of the biological properties of venoms of some old world vipers (subfamily viperinae). Int J Biochem 24: 331-336.

64. Cheng SC, Burton GW, Ingold KU, Foster DO (1987) Chiral discrimination in the exchange of alpha-tocopherol stereoisomers between plasma and red blood cells. Lipids 22: 469-473.

65. Feki M, Souissi M, Mebazaa A (2001) Vitamin E: structure, metabolism, and functions. Ann Med Intene 152: 384-391.

66. Mukherjee AK, Ghosal SK, Maity C (1998) Effect of oral supplementation of vitamin $\mathrm{E}$ on the hemolysis and erythrocyte phospholipid-splitting action of cobra and viper venoms. Toxicon 36: 657-664

67. Jurak M, Minones Conde J (2013) Characterization of the binary mixed monolayers of $\alpha$-tocopherol with phospholipids at the air-water interface. Biochim Biophys Acta 1828: 2410-2418.

68. Cogo JC, Prado-Franceschi J, Cruz-Hofling MA, Corrado AP, RodriguesSimioni $L$ (1993) Effect of Bothrops insularis venom on the mouse and chick nerve-muscle preparation. Toxicon 31: 1237-1247.

69. Garcia Denegri ME, Acosta OC, Huancahuire-Vega S, Martins-de-Souza D, Marangoni S, et al. (2010) Isolation and functional characterization of a new acidic PLA(2) Ba Spll RP4 of the Bothrops alternatus snake venom from Argentina. Toxicon 56: 64-74. 